\title{
Teratogenic Effect of Ethylene Glycol-Methyl Cellosolve Mixture in Rats. II. Craniofacial and Limb Abnormalities
}

\author{
Teratogénesis por Etilenglicol-Metilcelosolve en Ratas. II.Anormalidades Craneofaciales y de Miembros
}

${ }^{*, * *}$ Isabel García-Peláez; ${ }^{* * *}$ Oswaldo M. Aguirre-Luna; ${ }^{* * *}$ Dolores Saavedra-Ontiveros \& ${ }^{* * * *}$ Manuel Arteaga-Martínez

GARCÍA-PELÁEZ, I.; AGUIRRE-LUNA, O. M.; SAAVEDRA-ONTIVEROS, D. \& ARTEAGA-MARTÍNEZ, M. Teratogenic effect of ethylene glycol-methyl cellosolve mixture in rats. II. Craniofacial and limb abnormalities. Int. J. Morphol., 28(4):1173-1180, 2010.

SUMMARY: We investigated the teratogenic effect of an ethylene glycol-methyl cellosolve mixture on gestating Wistar rats, that received a daily intraperitoneal dose of different concentration of the mixture on day 8 of gestation until day 20. Multivariate analysis and Post-Hoc Bonferroni tests were used and relative risk and attributable fraction were calculated. In rats treated with the mixture the number of live fetuses decreased and reabsorptions increased with increasing concentrations of the mixture, as well as the number of abnormal fetuses. Abnormalities consisted mainly in atypical craniofacial morphology, protruding tongue, edema, signs of growth delay and shorter limbs, their frequency and severity increased at higher concentrations of the mixture. We conclude that the ethylene glycol-methyl cellosolve mixture possesses a higher teratogenic potential than each of its constituents separately, producing external fetal abnormalities, growth delay, and increased fetal death.

KEY WORDS: Ethylene glycol; Glycol ethers; Methyl cellosolve; Rat fetuses; Teratogenesis.

\section{INTRODUCTION}

In 1992, 44 patients between 16 and 19 years of age, affected physically and mentally at birth, were identified in the city of Matamoros, Tamaulipas, Mexico, all had as common antecedent that their mothers were workers at an assembly plant, having been in direct contact, without appropriate protection, with a mixture of different industrial solvents during gestation. This gave rise to the establishment of a new teratogenic syndrome, not previously described, originated by the prenatal exposure to industrial solvents: ethylene glycol $\left(\mathrm{HO}-\mathrm{CH}_{2}-\mathrm{CH}_{2}-\mathrm{OH}\right)$ and methyl cellosolve ( $\mathrm{HO}-\mathrm{CH}_{2}-\mathrm{CH}_{2}-\mathrm{O}-\mathrm{CH}_{3}$ ) (Saavedra-Ontiveros et al., 1996; Saavedra et al., 1997; Saavedra et al., 1998). The teratogenic action of each one of the solvents was confirmed in an experimental study in rats, and found morphological alterations more or less similar to those observed in the patients, as well as microscopic alterations of the central nervous system compatible with the functional alterations observed in the patients (Saavedra-Ontiveros et al.; Saavedra et al., 1997; Saavedra et al., 1998).
In a previous investigation we also demonstrate the reproductive damage produced by a mixture of both solvents in rats, when this mixture was applied intraperitoneally at different doses; in such investigation, we also observed an abnormal external morphology in a high proportions of live fetuses, mainly craniofacial abnormal shape and apparently short limbs. The purpose of this new paper is to report the morphological findings of these fetuses.

\section{MATERIAL AND METHOD}

An experimental blind and transverse study was performed in 35 pregnant Wistar rats, maintained under standard conditions in the general bioterium of the "Federico Gómez" Children's Hospital of Mexico City. The rats were randomly divided in three main groups: Group A or control group $(\mathrm{n}=5)$, those not receiving any substance, but

Facultad de Medicina de la Universidad Nacional Autónoma de México. México.

** Escuela de Medicina de la Universidad Panamericana, México.

**** Hospital Infantil de México "Federico Gómez", México.

Research performed at Hospital Infantil de México "Federico Gómez" and Department of Anatomy, Facultad de Medicina UNAM. México, D.F., México. 
maintained under the same conditions as the other groups. Group B or saline solution group $(n=5)$, those that were injected intraperitoneally a daily dose of $0.5 \mathrm{ml}$ saline solution at days 8 to 20 of gestation. Group $\mathrm{C}$ or a mixture of ethylene glycol-methyl cellosolve in saline solution $(\mathrm{n}=$ 25 ), those that were injected intraperitoneally a daily dose of $0.5 \mathrm{ml}$ of this mixture at different concentrations, and divided into five subgroups:

Subgroup C1. Ethylene glycol-methyl cellosolve solution at $1.25 \%(\mathrm{n}=5)$

Subgroup C2. Ethylene glycol-methyl cellosolve solution at $2.5 \%(\mathrm{n}=5)$

Subgroup C3. Ethylene glycol-methyl cellosolve solution at $5 \%(\mathrm{n}=5)$

Subgroup C4. Ethylene glycol-methyl cellosolve solution at $10 \%(n=5)$

Subgroup C5. Ethylene glycol-methyl cellosolve solution at $20 \%(n=5)$

When the rats reached the 21st day of gestation they were anesthetized by ether inhalation and the fetuses were obtained by cesarean section; once the fetuses had been obtained, the mothers were killed by applying a lethal anesthetic dose. The number of alive, dead fetuses, and reabsorptions of each one of the litters was registered. The fetuses were fixed by immersion in $5 \%$ formalin buffer during 72 hours, and subjected to qualitative and quantitative analysis.

Qualitative analysis. Aimed at determining whether the fetal external morphology was normal and corresponded to the gestational age, all the fetuses were observed under a Nikon
SMZ-10 stereoscopic binocular microscope; special emphasis was made on observing the integrity of the structures and the harmony of their segments.

Quantitative analysis. Aimed at determining the fetal size and weight, all the fetuses were weighed in a Chyo JL-180 digital scale, and their crown-rump length (C-R length) was measured by means of a Vernier caliper.

To quantify the apparent alterations observed in some of the fetuses, different segments of the anterior and posterior limbs, and some craniofacial diameters and distances were measured in all live fetuses (Fig. 1).

Segments of fore limb. In the fore limbs, the middle and distal thirds were measured together, i.e., the distance from the elbow joint until the distal end of the longest finger in the paw (elbow-paw length) (Fig. 1A). The measurement of the proximal third of this limb (shoulder-elbow length) could not be carried out because of lack of a precise reference point in the proximal end.

Segments of hind limb. In the hind limbs, the middle and distal thirds were measured separately: the middle third from the knee until the heel (knee-heel length), and the distal third, corresponding to the length of the foot to the end of the longest finger (foot length) (Fig. 1A). As in the forelimb, the proximal third of this limb (hip-knee length) could not be measured because of lack of a precise reference point in the proximal end.

Craniofacial measurements. In the frontal plane, the biparietal diameter (at the base of the skull) and the distance

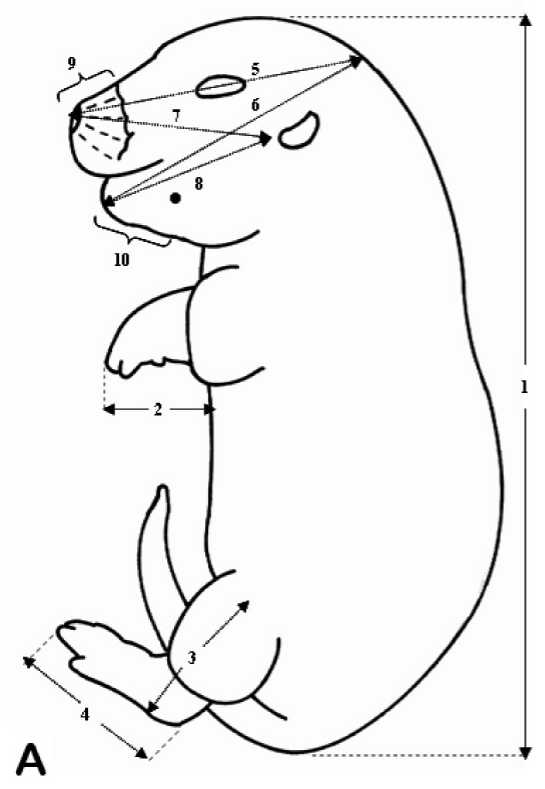

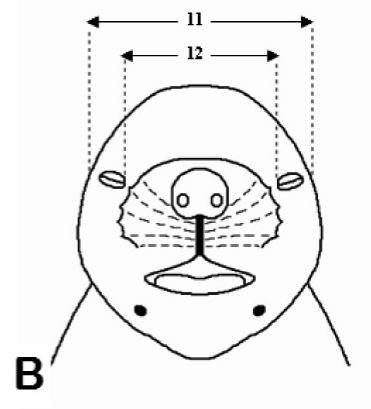

Fig. 1. Schematic representation of a rat fetus showing the different reference points used in this study. A. Left lateral view of the fetus. B. Frontal view of the craniofacial region. (1) CR length. (2) Elbow-paw length. (3) Knee-heel length. (4) Foot length. (5) Nasal-occipital length. (6) Chin-occipital length. (7) Nasalauricular length. (8) Chin-auricular length. (9) Nasal length. (10) Chin length. (11) Biparietal diameter. (12) Inner eye canthus length. 
between the inner eye canthus (Fig. 1B) were measured. In the saggital plane, the nasal-occipital length, chinoccipital length, nasal-auricular length, chin-auricular length, nasal length, and mandibular length were measured (Fig. 1A).

Each measurement was performed by the same researcher three times, by means of a micrometric eyepiece in the stereoscopic microscope or with a Vernier caliper. To assess the intraobserver degree of concordance, the intraclass coefficient of correlation was calculated using SPSS ${ }^{\circledR}$ software (10.0 Windows $\left.{ }^{\circledR}\right)$.

Analysis of body proportions. To assess the harmonic or disharmonic growth of the fetal segments, the proportions of the C-R length were calculated in reference to each of the different linear measurements, considering those obtained in Group A (control) as the normal values. To determine statistical differences, a multivariate analysis (ANOVA) and a Post Hoc Bonferroni test were performed; additionally we calculated the relative risk and the attributable fraction, using SPSS ${ }^{\circledR}$ software (10.0 Windows $\left.{ }^{\circledR}\right)$.

\section{RESULTS}

Qualitative analysis. In group A (control) 44 live fetuses were obtained from the five litters of this group, whereas in group B (saline solution) 50 live fetuses were obtained from their five litters. The external morphological characteristics of all the live fetuses of groups A and B were normal (Fig. 2A) (Table I).

In subgroup $\mathrm{C} 1$ (solution at $1.25 \%) 36$ live fetuses were found in the five litters. The external morphology was normal in 9 (25\%) and abnormal in 27 (75\%) (Table I). Of these nine normal fetuses, eight corresponded to a same litter of 10 fetuses, in which the two remaining fetuses were abnormal; the other normal fetus corresponded to a litter of four fetuses, where the three remaining were abnormal. In the other three litters of this group, all the live fetuses $(4,6$, and 12, respectively) were abnormal. Of the five litters, the 27 abnormal fetuses showed the tongue protruding in variable degrees from the oral cavity, and one of them also showed signs of intrauterine growth retardation (Table I); several of
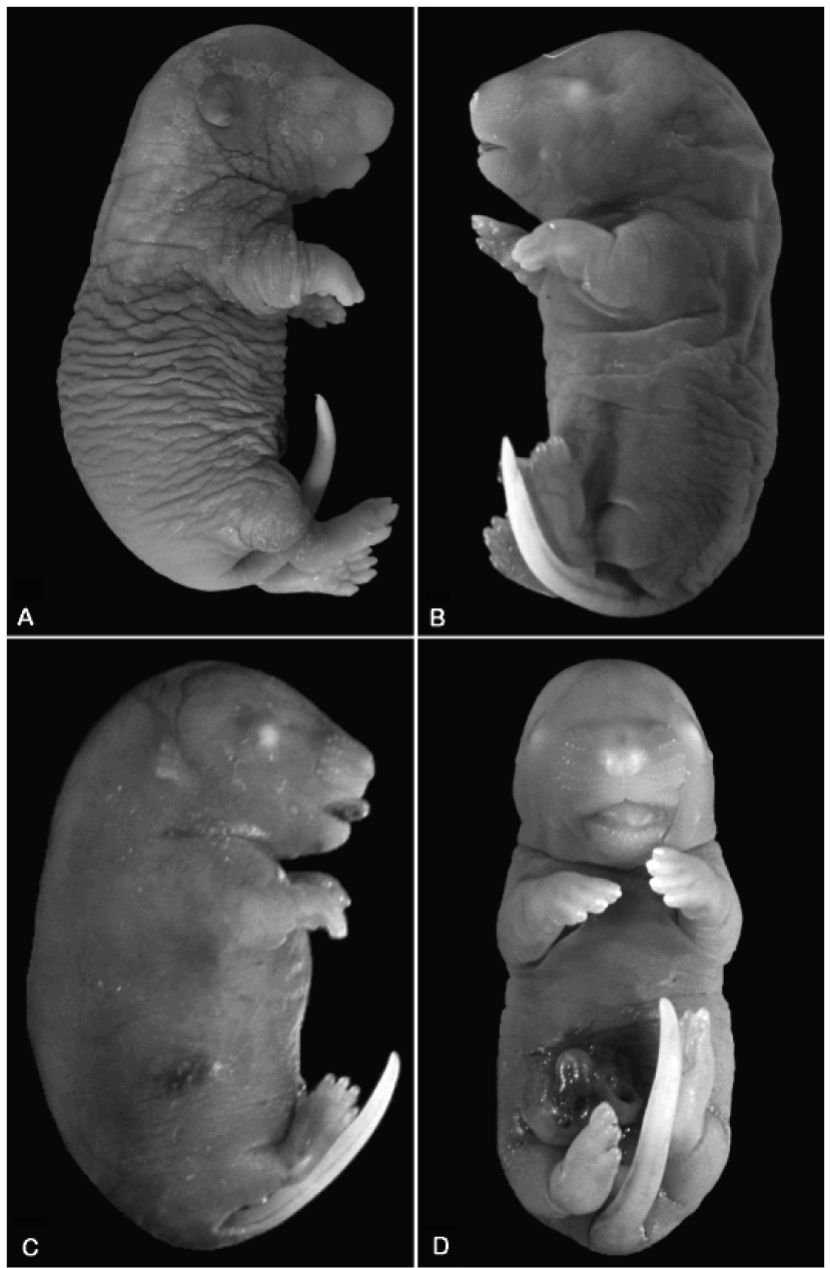

Fig. 2. Rat fetuses from the different studied groups. A. Fetus from group A (control) revealing normal external characteristics on day 21 of gestation. B, C. Fetuses from subgroups C2 (2.5\% mixture) and $\mathrm{C} 3$ (5\% mixture); note in both the rounded craniofacial morphology, the protruded tongue, the altered facial and limbs proportions, and generalized edema. In $\mathrm{C}$, note also the translucent eye lids. D. Fetus from subgroup C3 in frontal view showing the protruding tongue and an omphalocele.

Table I. External abnormalities.

\begin{tabular}{|c|c|c|c|c|c|c|}
\hline & & $\begin{array}{c}\text { Group A: } \\
\text { Control }\end{array}$ & $\begin{array}{c}\text { Group B: } \\
\text { Saline solution }\end{array}$ & $\begin{array}{l}\text { Group C1: } \\
1.25 \% \text { Mixt. }\end{array}$ & $\begin{array}{l}\text { Group C2: } \\
\text { 2.5\% Mixt. }\end{array}$ & $\begin{array}{l}\text { Group C3: } \\
5 \% \text { Mixt. }\end{array}$ \\
\hline \multicolumn{2}{|c|}{ Number of live fetuses } & 44 & 50 & 36 & 41 & 17 \\
\hline \multicolumn{2}{|c|}{ Number of normal fetuses } & 44 & 50 & 9 & 2 & 0 \\
\hline \multicolumn{2}{|c|}{ Number of abnormal fetuses } & 0 & 0 & 27 & 39 & 17 \\
\hline \multirow{3}{*}{ 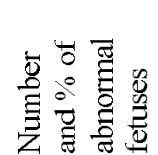 } & Tongue protrusion & 0 & 0 & $27(100 \%)$ & $39(100 \%)$ & $17(100 \%)$ \\
\hline & Edema & 0 & 0 & 0 & 0 & $17(100 \%)$ \\
\hline & Growth retardation & 0 & 0 & $1(3.7 \%)$ & $2(5.1 \%)$ & $9(52.9 \%)$ \\
\hline
\end{tabular}


these fetuses gave the impression of having altered facial and limb proportions.

In subgroup C2 (solution at 2.5\%) 41 live fetuses were obtained from the five litters. The external morphology was normal in $2(4.9 \%)$ and abnormal in $39(95.1 \%)$ (Table I). All the 39 abnormal fetuses showed protruded tongues in variable degrees (Fig. 2B), two of them also showed signs of intrauterine growth retardation (Table I). The percentage of abnormal fetuses between subgroups $\mathrm{C} 2$ and C1 was statistically different $(\mathrm{p}=0.02)$.

In subgroup C3 (solution at 5\%) 17 live fetuses were obtained from the five litters, and all fetuses showed abnormal morphology (100\%). They showed generalized edema of variable degrees and protruded tongues (Fig. $2 \mathrm{C}, \mathrm{D})$; nine (52.9\%) also exhibited signs of intrauterine growth retardation (Table I) and one presented omphalocele (Fig. 2D).

In subgroups $\mathrm{C} 4$ and $\mathrm{C} 5$ neither live nor dead fetuses were obtained. From the size of the reabsorptions, these seemed to correspond to very early stages.

\section{Quantitative analysis.}

Weight. The weight of the live fetuses in group A varied between 2.76-4.76 g; in group B, between $2.59-4.44 \mathrm{~g}$; in subgroup $\mathrm{C} 1$, between $2.39-4.33 \mathrm{~g}$; in subgroup $\mathrm{C} 2$, between 2.31-5.44 g; and in subgroup C3, between 1.88$3.18 \mathrm{~g}$. The average weight in each group is shown in Table II, showing no significant differences among groups A, B, $\mathrm{C} 1$, and $\mathrm{C} 2$, but the difference was significant when comparing each of these four groups with $\mathrm{C} 3(\mathrm{p}<0.001)$, diminishing in the latter an average of $26.8 \%$ with respect to group A (control).

Crown-rump length. The $\mathrm{C}-\mathrm{R}$ length of the live fetuses in group A fluctuated between 28.4-36.0 mm; in group B, between 28.0-34.9 mm; in subgroup C1, between 25.5-34.9 $\mathrm{mm}$; in subgroup $\mathrm{C} 2$, between $26.8-37.3 \mathrm{~mm}$; and in subgroup C3, between 24.9-32.4 $\mathrm{mm}$. The average C-R length in each group is depicted on Table II, revealing a significant difference $(\mathrm{p}<0.001)$ between subgroup $\mathrm{C} 3$ and group A (control), diminishing in the former an average of $8.9 \%$.

Segments of the fore limbs: The average of the elbow-paw length in each group is shown in Table II. As compared to group A (control), a slight decrease in measurements in subgroups $\mathrm{C} 1$ and $\mathrm{C} 2$ can be observed; the difference was larger in $\mathrm{C} 3,20.5 \%$ smaller than in group A.
Segments of the hind limbs. The average lengths of the medial and distal segments in each group are shown in Table II. In comparison to group A (control), a slight decrease in subgroups $\mathrm{C} 1$ and $\mathrm{C} 2$ measurements can be observed, whereas in $\mathrm{C} 3$ the decrement is larger and even more evident in the middle third (knee-heel) with an average $23.9 \%$ smaller than in group A (control).

Craniofacial measurements. Table II depicts the average of these measurements in each group and the difference between all subgroups and group A. A slight decrease in values of subgroups $\mathrm{C} 1$ and $\mathrm{C} 2$, and a bigger one in $\mathrm{C} 3$ with regard to group A (control) was observed. This decrease was smaller in the measurements made in the frontal plane (biparietal diameter and in the distance between the inner canthus of the eyes) than in those made in the saggital plane. Among the saggital measurements, the decrease was bigger in those including the nose (nasaloccipital, nasal-auricular, and nasal length) than in those including the chin (chin-occipital, chin-auricular, and mandibular length), being in the former between 17.9$24.4 \%$ and in the latter between $11.5-23.3 \%$ less than in the control group.

Analysis of body proportions. For a better evaluation of the harmonic or disharmonic growth of the fetal segments, we calculated the proportion between the C-R length and each one of the other measurements, in each fetus from the different experimental subgroups. No differences in any of the proportions were found among the fetuses of groups A (control) and B (saline solution) (Table III).

In the fore limbs, the C-R length/elbow-hand length proportion showed a tendency to be increased in subgroups $\mathrm{C} 1, \mathrm{C} 2$, and $\mathrm{C} 3$, the latter showing an average proportion of 9.7 against 8.4 of group A (control) (Table III). The increment in this proportion in subgroup C 3 was statistically significant not only with regard to group A, but also with all the other groups $(\mathrm{p}<0.001)$, with a relative risk of 28 and attributable fraction of 0.96 .

In the hind limbs, the C-R length/knee-heel length proportion showed a tendency to be increased in subgroups C2 and C3 (Table III), and was statistically significant with regard to the other groups $(\mathrm{p}<0.01$ to $\mathrm{p}<0.001)$; in subgroup $\mathrm{C} 2$ the relative risk was of 14.5 and the attributable fraction of 0.93 , and in subgroup $\mathrm{C} 3$ of 33.7 and 0.97 , respectively. Regarding the C-R length/foot length proportion a slight increment in subgroups $\mathrm{C} 2$ and C3 was observed (Table III), being statistically significant between the latter and group A (control) ( $p<0.001)$ but not with the other groups, with a relative risk of 4.3 and attributable fraction of 0.81 . 
From the C-R length/craniofacial measurements proportions, those corresponding to the biparietal diameter, distance between the inner canthus of the eyes, and chinoccipital length did not show difference among the five groups (Table III). In contrast, the proportions of the C-R length with the nasal-auricular and with the chin-auricular length showed increments in subgroup C3 (Table III), being statistically significant with regard to all the other groups $(\mathrm{p}<0.001)$; the nasal-auricular length had a relative risk of 7.7 and attributable fraction of 0.87 , and the chin-auricular length a relative risk of 4 and attributable fraction of 0.8 . The proportion of the $\mathrm{C}-\mathrm{R}$ length with the nasal-occipital length also showed a significant increment $(\mathrm{p}<0.04$ to 0.001) in subgroups $\mathrm{C} 2$ and $\mathrm{C} 3$ with regard to the other groups (Table III), with a relative risk of 13 and 14, and attributable fraction of 0.93 and 0.94 , respectively. Finally, the proportions of the C-R length with the nasal and mandibular length presented a considerable increment in subgroups $\mathrm{C} 1, \mathrm{C} 2$, and $\mathrm{C} 3$ (Table III), which was statistically significant with regard to groups $\mathrm{A}$ and $\mathrm{B}$, as well as between $\mathrm{C} 3$ and subgroups $\mathrm{C} 1$ and $\mathrm{C} 2(\mathrm{p}<0.001)$; the relative risk and attributable fraction for the proportion of C-R length with the nasal length were: for subgroup $\mathrm{C} 1$ of 8.8 and 0.89 , for subgroup $\mathrm{C} 2$ of 11.8 and 0.92 , and for subgroup $\mathrm{C} 3$ of 42 and 0.97 ; for the proportion of C-R length with the mandibular length, the relative risk and attributable fraction were: for group $\mathrm{C} 1$ of 4.6 and 0.82 , for group $\mathrm{C} 2$ of 5.6 and 0.84 , and for group C 3 of 23 and 0.95 .

Table II. Quantitative study and segments decrease.

\begin{tabular}{|c|c|c|c|c|c|}
\hline & $\begin{array}{l}\text { Group A: } \\
\text { Control }\end{array}$ & $\begin{array}{l}\text { Group B: } \\
\text { Saline Solution }\end{array}$ & $\begin{array}{l}\text { Group C1: } \\
1.25 \% \text { Mixt. }\end{array}$ & $\begin{array}{l}\text { Group C2: } \\
2.5 \% \text { Mixt. }\end{array}$ & $\begin{array}{l}\text { Group C3: } \\
\text { Mixt. 5\% }\end{array}$ \\
\hline Weight & $\begin{array}{l}3.730 \mathrm{~g} \\
(\mathrm{SD}=0.554)\end{array}$ & $3.383 \mathrm{~g}(\mathrm{SD}=0.395)(-9.3 \%)$ & $\begin{array}{l}3.562 \mathrm{~g}(\mathrm{SD}=0.407) \\
(-4.5 \%)\end{array}$ & $\begin{array}{l}3.376 \mathrm{~g}(\mathrm{SD}=0.713) \\
(-9.5 \%)\end{array}$ & $\begin{array}{l}2.730 \mathrm{~g}(\mathrm{SD}=0.354) \\
(-26.8 \%)\end{array}$ \\
\hline C-R length & $\begin{array}{l}32.5 \mathrm{~mm} \\
(\mathrm{SD}=1.828)\end{array}$ & $31.5 \mathrm{~mm}(\mathrm{SD}=1.719)(-3.1 \%)$ & $\begin{array}{l}31.3 \mathrm{~mm}(\mathrm{SD}=2.092) \\
(-3.7 \%)\end{array}$ & $\begin{array}{l}31.3 \mathrm{~mm}(\mathrm{SD}=2.481) \\
(-3.7 \%)\end{array}$ & $\begin{array}{l}29.6 \mathrm{~mm}(\mathrm{SD}=2.098) \\
(-8.9 \%)\end{array}$ \\
\hline Elbow-paw length & $\begin{array}{l}3.9 \mathrm{~mm} \\
(\mathrm{SD}=0.209)\end{array}$ & $3.7 \mathrm{~mm}(\mathrm{SD}=0.161)(-5.1 \%)$ & $\begin{array}{l}3.6 \mathrm{~mm}(\mathrm{SD}=0.250) \\
(-7.7 \%)\end{array}$ & $\begin{array}{l}3.5 \mathrm{~mm}(\mathrm{SD}=0.292) \\
(-10.3 \%)\end{array}$ & $\begin{array}{l}3.1 \mathrm{~mm}(\mathrm{SD}=0.376) \\
(-20.5 \%)\end{array}$ \\
\hline Knee- heel length & $\begin{array}{l}7.1 \mathrm{~mm} \\
(\mathrm{SD}=0.387)\end{array}$ & $6.7 \mathrm{~mm}(\mathrm{SD}=0.277)(-5.6 \%)$ & $\begin{array}{l}6.5 \mathrm{~mm}(\mathrm{SD}=0.431) \\
(-8.4 \%)\end{array}$ & $\begin{array}{l}6.2 \mathrm{~mm}(\mathrm{SD}=0.671) \\
(-12.7 \%)\end{array}$ & $\begin{array}{l}5.4 \mathrm{~mm}(\mathrm{SD}=0.716) \\
(-23.9 \%)\end{array}$ \\
\hline Foot length & $\begin{array}{l}7.1 \mathrm{~mm} \\
(\mathrm{SD}=0.233)\end{array}$ & $6.9 \mathrm{~mm}(\mathrm{SD}=0.177)(-2.8 \%)$ & $\begin{array}{l}6.8 \mathrm{~mm}(\mathrm{SD}=0.265) \\
(-4.2 \%)\end{array}$ & $\begin{array}{l}6.7 \mathrm{~mm}(\mathrm{SD}=0.407) \\
(-5.6 \%)\end{array}$ & $\begin{array}{l}6.1 \mathrm{~mm}(\mathrm{SD}=0.383) \\
(-14.1 \%)\end{array}$ \\
\hline Biparietal diameter & $\begin{array}{l}9.5 \mathrm{~mm} \\
(\mathrm{SD}=0.350)\end{array}$ & $9.2 \mathrm{~mm}(\mathrm{SD}=0.343)(-3.2 \%)$ & $9.5 \mathrm{~mm}(\mathrm{SD}=0.326)$ & $\begin{array}{l}9.1 \mathrm{~mm}(\mathrm{SD}=0.441) \\
(-4.2 \%)\end{array}$ & $\begin{array}{l}8.5 \mathrm{~mm}(\mathrm{SD}=0.345) \\
(-10.5 \%)\end{array}$ \\
\hline Inner eye canthus length & $\begin{array}{l}6.0 \mathrm{~mm} \\
(\mathrm{SD}=0.232)\end{array}$ & $5.9 \mathrm{~mm}(\mathrm{SD}=0.151)(-1.7 \%)$ & $\begin{array}{l}5.8 \mathrm{~mm}(\mathrm{SD}=0.236) \\
(-3.3 \%)\end{array}$ & $\begin{array}{l}5.9 \mathrm{~mm}(\mathrm{SD}=0.160) \\
(-1.7 \%)\end{array}$ & $\begin{array}{l}5.5 \mathrm{~mm}(\mathrm{SD}=0.388) \\
(-8.3 \%)\end{array}$ \\
\hline Nasal-occipital length & $\begin{array}{l}14.5 \mathrm{~mm} \\
(\mathrm{SD}=0.550)\end{array}$ & $14.0 \mathrm{~mm}(\mathrm{SD}=0.384)(-3.4 \%)$ & $\begin{array}{l}13.6 \mathrm{~mm}(\mathrm{SD}=0.586) \\
(-6.2 \%)\end{array}$ & $\begin{array}{l}13.1 \mathrm{~mm}(\mathrm{SD}=0.579) \\
(-9.6 \%)\end{array}$ & $\begin{array}{l}12.3 \mathrm{~mm}(\mathrm{SD}=0.617) \\
(-15.2 \%)\end{array}$ \\
\hline Chin-occipital length & $\begin{array}{l}13.9 \mathrm{~mm} \\
(\mathrm{SD}=0.472)\end{array}$ & $13.4 \mathrm{~mm}(\mathrm{SD}=0.381)(-3.6 \%)$ & $\begin{array}{l}13.4 \mathrm{~mm}(\mathrm{SD}=0.522) \\
(-3.6 \%)\end{array}$ & $\begin{array}{l}13.0 \mathrm{~mm}(\mathrm{SD}=0.471) \\
(-6.5 \%)\end{array}$ & $\begin{array}{l}12.3 \mathrm{~mm}(\mathrm{SD}=0.656) \\
(-11.5 \%)\end{array}$ \\
\hline Nasal-a uricular length & $\begin{array}{l}12.3 \mathrm{~mm} \\
(\mathrm{SD}=0.537)\end{array}$ & $12.1 \mathrm{~mm}(\mathrm{SD}=0.373)(-1.6 \%)$ & $\begin{array}{l}11.7 \mathrm{~mm}(\mathrm{SD}=0.574) \\
(-4.9 \%)\end{array}$ & $\begin{array}{l}11.7 \mathrm{~mm}(\mathrm{SD}=0.551) \\
(-4.9 \%)\end{array}$ & $\begin{array}{l}10.1 \mathrm{~mm}(\mathrm{SD}=0.645) \\
(-17.9 \%)\end{array}$ \\
\hline Chin-auricular length & $\begin{array}{l}11.1 \mathrm{~mm} \\
(\mathrm{SD}=0.531)\end{array}$ & $11.1 \mathrm{~mm}(\mathrm{SD}=0.414)$ & $\begin{array}{l}10.8 \mathrm{~mm}(\mathrm{SD}=0.503) \\
(-2.7 \%)\end{array}$ & $\begin{array}{l}10.9 \mathrm{~mm}(\mathrm{SD}=0.461) \\
(-1.8 \%)\end{array}$ & $\begin{array}{l}9.4 \mathrm{~mm}(\mathrm{SD}=0.612) \\
(-15.3 \%)\end{array}$ \\
\hline Nasal length & $\begin{array}{l}4.1 \mathrm{~mm} \\
(\mathrm{SD}=0.250)\end{array}$ & $3.9 \mathrm{~mm}(\mathrm{SD}=0.210)(-4.9 \%)$ & $\begin{array}{l}3.7 \mathrm{~mm}(\mathrm{SD}=0.253) \\
(-9.8 \%)\end{array}$ & $\begin{array}{l}3.6 \mathrm{~mm}(\mathrm{SD}=0.241) \\
(-12.2 \%)\end{array}$ & $\begin{array}{l}3.1 \mathrm{~mm}(\mathrm{SD}=0.248) \\
(-24.4 \%)\end{array}$ \\
\hline Chin length & $\begin{array}{l}4.3 \mathrm{~mm} \\
(\mathrm{SD}=0.258)\end{array}$ & $4.1 \mathrm{~mm}(\mathrm{SD}=0.250)(-4.6 \%)$ & $\begin{array}{l}3.8 \mathrm{~mm}(\mathrm{SD}=0.261) \\
(-11.6 \%)\end{array}$ & $\begin{array}{l}3.8 \mathrm{~mm}(\mathrm{SD}=0.287) \\
(-11.6 \%)\end{array}$ & $\begin{array}{l}3.3 \mathrm{~mm}(\mathrm{SD}=0.315) \\
(-23.3 \%)\end{array}$ \\
\hline
\end{tabular}

Table III. C-R Length/All measurements proportion.

\begin{tabular}{|c|c|c|c|c|c|}
\hline & $\begin{array}{c}\text { Group A: } \\
\text { Control }\end{array}$ & $\begin{array}{c}\text { Group B: } \\
\text { Saline solution }\end{array}$ & $\begin{array}{c}\text { Group C1: } \\
1.25 \% \text { Mixt. }\end{array}$ & $\begin{array}{r}\text { Group C2: } \\
2.5 \% \text { Mixt. }\end{array}$ & $\begin{array}{l}\text { Group C3: } \\
\text { 5\% Mixt. }\end{array}$ \\
\hline Elbow-paw length & $\mathrm{x}=8.4(7.4$ to 9.6$)$ & $\mathrm{x}=8.6(7.3$ to 9.5$)$ & $\mathrm{x}=8.6(6.9$ to 10.0$)$ & $\mathrm{x}=8.9(7.7$ to 9.6$)$ & $\mathrm{x}=9.7(8.2$ to 12.5$)$ \\
\hline Knee-heel length & $x=4.6(4.2$ to 5.4$)$ & $\mathrm{x}=4.7(4.3$ to 5.1$)$ & $\mathrm{x}=4.8(4.0$ to 5.4$)$ & $x=5.1(4.4$ to 6.1$)$ & $x=5.5(4.6$ to 7.3$)$ \\
\hline Foot length & $\mathrm{x}=4.5(4.0$ to 5.2$)$ & $\mathrm{x}=4.6(4.1$ to 5.1$)$ & $x=4.6(3.9$ to 5.2$)$ & $\mathrm{x}=4.7(4.3$ to 5.0$)$ & $\mathrm{x}=4.8(4.5$ to 5.5$)$ \\
\hline Biparietal diameter & $\mathrm{x}=3.4(3.1$ to 3.9$)$ & $\mathrm{x}=3.4(3.1$ to 3.9$)$ & $x=3.3(2.6$ to 3.7$)$ & $\mathrm{x}=3.4(3.1$ to 3.8$)$ & $\mathrm{x}=3.5(3.1$ to 4.1$)$ \\
\hline Inner eye canthus length & $\mathrm{x}=5.4(4.9$ to 6.3$)$ & $x=5.3(4.7$ to 6.0$)$ & $x=5.3(4.7$ to 5.9$)$ & $x=5.2(4.6$ to 5.9$)$ & $\mathrm{x}=5.3(4.4$ to 5.9$)$ \\
\hline Nasal-occipital length & $\mathrm{x}=2.2(2.0$ to 2.5$)$ & $\mathrm{x}=2.2(2.0$ to 2.5$)$ & $\mathrm{x}=2.3(1.9$ to 2.5$)$ & $\mathrm{x}=2.4(2.1$ to 2.7$)$ & $\mathrm{x}=2.4(2.2$ to 2.7$)$ \\
\hline Chin-occipital length & $x=2.3(2.1$ to 2.6$)$ & $x=2.3(2.1$ to 2.6$)$ & $x=2.3(1.9$ to 2.6$)$ & $\mathrm{x}=2.4(2.1$ to 2.8$)$ & $x=2.4(2.1$ to 2.6$)$ \\
\hline Nasal-auricular length & $\mathrm{x}=2.6(2.3$ to 3.0$)$ & $\mathrm{x}=2.6(2.4$ to 2.9$)$ & $x=2.6(2.2$ to 2.9$)$ & $\mathrm{x}=2.6(2.4$ to 2.9$)$ & $\mathrm{x}=2.9(2.7$ to 3.3$)$ \\
\hline Chin-a uricular length & $\mathrm{x}=2.9(2.6$ to 3.4$)$ & $\mathrm{x}=2.8(2.5$ to 3.1$)$ & $x=2.9(2.4$ to 3.3$)$ & $\mathrm{x}=2.9(2.6$ to 3.2$)$ & $\mathrm{x}=3.1(2.8$ to 3.8$)$ \\
\hline Nasal length & $\mathrm{x}=7.9(6.7$ to 8.9$)$ & $\mathrm{x}=8.1(7.3$ to 9.4$)$ & $\mathrm{x}=8.5(7.2$ to 9.3$)$ & $\mathrm{x}=8.7(8.0$ to 9.7$)$ & $\mathrm{x}=9.6(8.3$ to 11.0$)$ \\
\hline Chin length & $x=7.6(6.4$ to 9.7$)$ & $\mathrm{x}=7.6(6.7$ to 8.6$)$ & $\mathrm{x}=8.2(7.4$ to 9.0$)$ & $\mathrm{x}=8.3(6.5$ to 9.0$)$ & $\mathrm{x}=9.0(7.7$ to 11.2$)$ \\
\hline
\end{tabular}




\section{DISCUSSION}

As is well known, when a potentially teratogenic agent comes in contact with an embryo or fetus, during development, it interacts with it, being able to produce some type of alteration. The final result of this interaction can be: morphological or functional abnormalities of the conceptus, delay in intrauterine growth and development, fetal death, or morpho-functional abnormalities in the conceptus. This will depend on the agent's nature, the precise age of the embryo or fetus at the moment of interaction, the dose of the agent, and the genetic susceptibility and the conceptus' capacity to respond before the teratogenic insult.

A few years ago, we demonstrated the teratogenic effect of ethylene glycol and methyl cellosolve, when applying each one of them independently in gestating Wistar rats (Saavedra-Ontiveros et al., 1996; Saavedra et al., 1997; Saavedra et al., 1998). That research was performed to complete the clinical and epidemiological study of a group of patients of a border city of the north of Mexico, whose mothers had been in contact with a mixture of these solvents during the gestation of the patients (Saavedra-Ontiveros et al., 1996; Saavedra et al., 1997). The alterations found in the fetuses from the rats exposed to ethylene glycol were more or less similar to those observed in the fetuses exposed to methyl cellosolve, and some of these characteristics were also similar or equivalent to those observed in the patients. However, not all the alterations found in the rat fetuses were observed in the patients, neither were all the characteristics of the patients found in the rat fetuses; it was concluded that this could be due to a species-specific effect and/or that, when combining both substances, the teratogenic effect was slightly different from that exerted independently. To clarify this question, we performed the present research using a mixture of both solvents at equal parts in saline solution, applied intraperitoneally on the same days at which they were applied independently in the previous studies.

All the live fetuses of group A (control) showed normal external morphology (Fig. 2A), demonstrating normality of the used strain. In the same way, all the live fetuses from group B (saline solution) showed a normal phenotype, which indicates that injection of the vehicle used to dissolve the ethylene glycol-methyl cellosolve mixture did not have either toxic or teratogenic effects on the fetuses. Of the 11 normal live fetuses from the rats treated with the solvents, nine were of subgroup $\mathrm{C} 1$, which received the lowest concentration of the mixture $(1.25 \%)$, and two fetuses belonged to subgroup $\mathrm{C} 2$, which was injected an intermediate concentration (2.5\%); no fetuses with normal characteristics were found in subgroup C3 (mixture at 5\%). This agrees with the teratogenic principle that states that at a larger concentration of a teratogen there is a greater amount of affected individuals (Wilson, 1997). It is noteworthy that from the nine normal fetuses of subgroup C1, eight corresponded to one litter, which allows inferring a stronger resistance in their mother to the effect of the solvents.

In the three subgroups treated with the ethylene glycol-methyl cellosolve mixture in which live fetuses were obtained, external fetal alterations were observed, their frequency increasing significantly with higher concentrations of the solvents (subgroups $\mathrm{C} 2$ and C3) (Table I). This finding also agrees with the last principle of teratogenesis, i.e., at higher concentrations the frequency of fetal alterations increased (Wilson).

The most common observed alteration was the tongue protruding from the oral cavity, which was observed in all the abnormal fetuses (Fig. 2B, C, D). Macroscopically the tongue was normal in its position, morphology, and consistency, indicating that there was not a primary alteration of the tongue, but rather due to a too small oral cavity because of maxillary and/or mandibular reduction, although it cannot be discarded that some degree of lingual edema could also be involved.

Generalized edema was observed only in the 17 live fetuses of subgroup C3 (mixture at $5 \%$ ). In the previous research, in which the solvents were independently applied (Saavedra-Ontiveros et al.; Saavedra et al., 1997) generalized edema was also observed, more severely in the methyl cellosolve-treated rats than in the ethylene glycol-treated rats, but both with a lower frequency and at a higher dose than those used in this study, indicating that this effect is stronger when mixing the solvents.

Regarding growth retardation, this was evidenced by qualitative and quantitative characteristics. In the first case, the most evident sign was the eye-lids translucence (compare $\mathrm{C}$ with A, in Fig. 2), a normal characteristic until day 16 or 17 post-fertilization, but it is not observed in older fetuses. Growth retardation was also assessed by the weight and size of the fetuses; we used the weight and size of the fetuses from the control group as reference. We found a marked decrease in these parameters in the 
fetuses exposed to the highest concentration yielding live fetuses (subgroup C3, 5\%). The decrease in fetal size has not yet been reported in any biological model with either ethylene glycol or methyl cellosolve, which suggests that the mixture of the solvents is responsible for this alteration, or that this parameter has not been considered by other authors. In contrast, decrease in weight has been reported in the mouse and in the rat, with both substances, ethylene glycol (Price et al., 1985) and methyl cellosolve (Nelson et al., 1984; Toraason \& Breitenstein, 1988; Hardin \& Eisenmann, 1987). Decreases in fetal weight and size are alterations commonly observed as effects of different teratogenic agents, and they can be due to the alterations taking place either directly in the fetus or in the placenta, as has been pointed out for methyl cellosolve, which produces vascular alterations and peripheral necrosis of the placenta (Khera, 1993) or maternal poisoning (Guittina et al., 2000).

Measurements of the anterior and posterior limbs length evidenced their apparent shortening (Table II). The elbow-paw length showed a decrease in its absolute value, especially in subgroup C3 in which it was $20.5 \%$ smaller than in group A; a similar situation was observed in the knee-heel and foot lengths, which in this same subgroup C3 were $23.9 \%$ and $14.1 \%$ smaller than in group A. This shortening was even more evident when comparing the proportions of these segments with the C-R length (Table III), since these proportions indicate the decrease of the segment independently from the total length of the fetus; comparison of the elbow-paw, knee-heel, and foot length proportions to the C-R length between subgroup C3 and group A gave values of 9.7 vs. 8.4, 5.5 vs. 4.6, and 4.8 vs. 4.5 , respectively (Table III). In actual or relative values, the decrease was directly proportional to the dose, and in subgroup $\mathrm{C} 3$ the relative risk and attributable fraction were high, which indicates that this alteration is due to the ethylene glycol-methyl cellosolve mixture. It has not yet been reported in the literature that ethylene glycol produces shortening of the limbs, but it does produce delay in ossification in rats (Carney et al., 1999; Maronpot et al., 1983). On the other hand, shortening of the limbs produced by methyl cellosolve has been reported (Saavedra et al., 1997; Ritter et al., 1985), which suggests that methyl cellosolve was responsible for the shortening of limbs in our experiment, but with a more powerful effect due to its combination with ethylene glycol, since this effect was observed at a lower dose than when used alone.

When analyzing the craniofacial measurements it becomes evident that the ethylene glycol-methyl cellosolve mixture produced a reduction of the nose and the chin and this was directly proportional to the doses (Tables II and III). This reduction could account for the protruded tongue by the size-diminution of the oral cavity. The relative risk and the attributable fraction were bigger for the nose than for the chin. In our previous research, when using separately each solvent, we found that ethylene glycol did not produce alterations in the craniofacial measurements, whereas methyl cellosolve produced such alterations although at higher concentrations than those used for the mixture in this study (Saavedra et al., 1998). These alterations have not been reported by other authors in experimental models. In the clinical study performed in the patients of the city of Matamoros (Saavedra-Ontiveros et al.; Saavedra et al., 1997), retrusion of the middle third of the face was observed, as well as nasal alterations, that could be equivalent to the decrease of nasal length and of the naso-auricular and naso-occipital distances encountered in the affected rat fetuses of the present study; hypertelorism and prognatism were observed in the patients but these characteristics were not seen in the rat fetuses, rather the rat fetuses presented shortening of the chin and a decrease in the chin-auricular distance, alterations that are probably species-specific.

In our previous research, we demonstrated the independent teratogenic effect of ethylene glycol and methyl cellosolve and found some similar alterations to those found in the present study, such as the craniofacial shape and size, the generalized edema, the protruded tongue, and limbs shortening (Saavedra-Ontiveros et al.; Saavedra et al., 1997, Saavedra et al., 1998). Besides, in the previous research, other alterations, not observed in the present study, were found, such as cutis aplasia, oligodactyly, pseudoterigium colli, and caudal implantation of the anterior limbs, which could be a direct effect of the solvents, which, when combined, lose some of their effects on the embryonic and fetal structures.

Our results allow us to conclude that chronic exposure of gestating rats to the ethylene glycol-methyl cellosolve mixture has a more powerful teratogenic effect than when they act separately, producing a diminution of the nasal region and of the anterior and posterior limbs. The other alterations exhibited by the patients and not reproduced in the rat model could be due to a species-specific effect. The solvents mixture also fostered embryo mortality and growth retardation as compared to the findings when applied separately. These findings are very relevant since, in the working environment, it is very frequent to use these chemicals combined and even with other solvents, therefore they pose a greater risk of developmental alterations than those reported when used alone. 
GARCÍA-PELÁEZ, I.; AGUIRRE-LUNA, O. M.; SAAVEDRA-ONTIVEROS, D. \& ARTEAGA-MARTÍNEZ, M. Teratogénesis por etilenglicol-metilcelosolve en ratas. II. Anormalidades craneofaciales y de miembros. Int. J. Morphol., 28(4):1173-1180, 2010.

RESUMEN: Se investigó el efecto teratogénicos de una mezcla de etilenglicol y metilcelosolve en ratas gestantes, las cuales recibieron por vía intraperitoneal una dosis diaria, a diferentes concentraciones de la mezcla, del día 8 al día 20 de gestación. Se utilizaron las pruebas de análisis multivariado y Post-Hoc de Bonferroni, y se calcularon el riesgo relativo y la fracción atribuible. En las ratas tratadas con la mezcla el número de fetos vivos disminuyó y las reabsorciones y el número de fetos anormales aumentaron a mayor concentración de los solventes. Las anormalidades fetales consistieron principalmente en morfología atípica craneofacial, protrusión de la lengua, edema, signos de retraso de crecimiento y acortamiento de extremidades, y su frecuencia y severidad se incrementó a mayor concentración de la mezcla. Concluimos que la mezcla de etilenglicol-metilcelosolve tiene mayor efecto teratogénico que cuando actúan cada uno de los solventes por separado, produciendo anormalidades fetales externas, retraso del crecimiento y aumento de muerte fetal.

PALABRAS CLAVE: Etilenglicol; Éteres de glicol; Metilcelosolve; Fetos de rata; Teratogénesis.

\section{REFERENCES}

Carney, E. W.; Freshour, N. L.; Dittenber, D. A. \& Dryzga, M. D. Ethylene glycol developmental toxicity: unraveling the roles of glycolic acid and metabolic acidosis. Toxicol. Sci., 50:117-26, 1999.

Guittina, P.; Eléfant, E. \& Saint-Salvi, B. Hierarchization of animal teratology findings for improving the human risk evaluation of drugs. Reprod. Toxicol., 14:369-75, 2000.

Hardin, B. D. \& Eisenmann, C. J. Relative potency of four ethylene glycol ethers for induction of paw malformations in the CD-1 mouse. Teratology, 35:321-8, 1987.

Khera, K. S. Mouse placenta: hemodynamics in the main maternal vessel and histopathologic changes induced by 2methoxyethanol and 2-methoxyacetic acid following maternal dosing. Teratology, 47:299-310, 1993.

Maronpot, R. R.; Zelenak, J. P.; Weaver, E. V. \& Smith, N. J. Teratogenicity study of ethylene glycol in rats. Drug Chem. Toxicol., 6:579-94, 1983.

Nelson, B. K.; Setzer, J. V.; Brightwell, W. S.; Mathinos, P. R.; Kuczuk, M. H.; Weaver, T. E.; et al. Comparative inhalation teratogenicity of four glycol ether solvents and an amino derivative in rats. Environ. Health Perspect., 57:261-71, 1984.

Price, C. J.; Kimmel, C. A.; Tyl, R. W. \& Marr, M. C. The developmental toxicity of ethylene glycol in rats and mice. Toxicol. Appl. Pharmacol., 81:113-27, 1985.

Ritter, E. J.; Scott, W. J. Jr.; Randall, J. L. \& Ritter, J. M. Teratogenicity of dimethoxyethyl phthalate and its metabolites methoxyethanol and methoxyacetic acid in the rat. Teratology, 32:25-31, 1985.

Saavedra, D.; Arteaga, M. \& Tena, M. Industrial contamination with glycol ethers resulting in teratogenic damage. Ann. $N$. Y. Acad. Sci.,. 837:126-37, 1997.

Saavedra, D.; Tena, M.; Cornejo, L. R.; Servín, L. M. \& Arteaga, M. Alteraciones craneofaciales y del sistema nervioso central producidas por solventes orgánicos. Estudio experimental en ratas. Rev. Hosp. Gral. Dr. M. Gea González, 1:8-15, 1998.

Saavedra-Ontiveros, D.; Arteaga-Martínez, M.; SerranoMedina, B.; Reynoso-Arizmendi, F.; Prada-Garay, N. \& Cornejo-Roldán, L. R. Contaminación industrial con solventes orgánicos como causa de teratogénesis. Salud Pública Mex., 38:3-12, 1996.

Toraason, M. \& Breitenstein, M. Prenatal ethylene glycol monomethyl ether (EGME) exposure produces electrocardiographic changes in the rat. Toxicol. Appl. Pharmacol., 95(2):321-7, 1988.

Wilson, J. G. Current status of teratology. General principles and mechanisms derived from animal studies. In: Wilson, J. G. \& Fraser, F. C. (Eds). Handbook of Teratology. New York, Plenum Press, 1997. pp.47-74.

Correspondence to:

Dr. Manuel Arteaga-Martínez

Jefe del Departamento de Anatomía

Facultad de Medicina UNAM

Ciudad Universitaria, O4510

México D.F. - MÉXICO

Tel. (+52-55) 56-23-24-23

Fax: (+52-55) 56-23-24-25

Email: manuelarteagamartinez@hotmail.com smam48@gmail.com

Received: 21-07-2010

Accepted: 23-09-2010 